\title{
THE RELIGION OF JESUS
}

SHIRLEY JACKSON CASE

The University of Chicago

The personal religious life of Jesus has not always received the consideration it deserves. Attention has been centered on other things. His miracle-working career, the theological implications of his teaching, metaphysical speculation about his unique personality, these things have too often been made the chief items of interest while his significance as a religious individual has been overlooked. Believers have been wont to look upon him so exclusively as the object of their own religious reverence, and consequently have sometimes removed him so far from the normal relations of a historical person, that they have been in danger of missing the inspiration to be derived from spiritual sympathy with hirn in his own deep religious experience.

This tendency dominated Christian thinking at an early date. In the earliest extant Christian literature, the epistles of Paul, reference to the earthly life and experiences of Jesus is conspicuously scanty. True, Paul had not been a personal disciple, but his opportunities for obtaining full information on the subject were abundant. Incidentally, too, he shows a closer acquaintance with certain phases of the early history than might at first sight be supposed; nevertheless interest in the heaven-exalted Messiah is paramount. As Paul saw it, it was primarily important to interpret Jesus' life as one of the last acts in a divine drama which was being worked out on the stage of human history within the narrow limits of the ancients' world-view. Paul's own belief in Jesus' resurrection, and the testimony of others who entertained a similar belief, seemed a sufficient guarantee of the correctness of this interpretation. ${ }^{x}$ Under these circumstances the thought of Jesus as a religious personage was a wholly unnatural, if not indeed an impossible, conception.

While Paul did not go back of his resurrection faith for his proof

I I Cor. I5: I f. 
of Jesus' messiahship, and so for the substantiation of his gospel, there were other Christian missionaries who did. The narrative of Mark is the earliest known literary example of this change of method. The same general type of interpretation, which places the formal and external elements in the foreground, is preserved, but additional evidence for the new faith is drawn from the pre-resurrection period. Paul was content to note that Jesus had been declared to be the Son of God through his resurrection;2 Mark is able to recall incidents in Jesus' life anticipating both the resurrection glory and the divine authentication of the Son. For example, at baptism a voice from above reveals to Jesus his divine sonship, ${ }^{3}$ and a similar declaration for the disciples' benefit is made at the time of the transfiguration, where certain favored followers are given a foretaste of the glory of Jesus' approaching resurrection. Mark however clearly intimates that the disciples did not appreciate the significance of this incident until they interpreted it in the light of their later faith. ${ }^{4}$

Paul attached considerable importance to the working of "powers" in the early church, seeing in it the Spirit's witness to Jesus' present supremacy. ${ }^{5}$ Mark is able to recount a whole series of events in Jesus' own activity which bear similar testimony to his supremacy. To be sure, Mark admits that the miraculous deeds of Jesus had not at the time produced any general belief in his messiahship; yet this failure was not due to the inadequacy of the attestation but to other causes such as the people's marvelous lack of faith, ${ }^{6}$ Jesus' refusal to permit the demons to make him known, ${ }^{7}$ or God's deliberate blinding of men that they might surely see and yet not perceive. ${ }^{8}$ Moreover, failure to recognize the presence of the Holy Spirit with Jesus in his capacity of miracle-worker is presented by Mark as the unpardonable sin, ${ }^{9}$ while Paul merely calls attention to the certainty of the divine spiritual presence with the believer who recognizes Jesus' lordship. ${ }^{\text {IO }}$

\footnotetext{
2 Rom. I:4; cf. Acts $2: 36$.

3 Mark I:II. 4 Mark 9:2-IO.

5 Gal. 3:2-5; I Cor. 12:9 f., 28 f.; II Cor. 12:12; Rom. 15:19.

${ }^{6}$ Mark 6:6.

7 Mark I:34; etc. 9 Mark 3:29 f.

8 Mark. $4: 12 ; 6: 52 ; 8: 17$ ff. Io I Cor. $12: 3$.
} 
The Spirit's activity was fundamental to the primitive Christian's new life. It is so represented by Paul as well as by the writer of Acts. ${ }^{\text {I }}$ Some such manifestation of the divine activity seems to have been regarded as a necessary mark of the genuineness of one's membership in the messianic community. This special experience probably came to the new convert about the time of his baptism. ${ }^{22}$ While Paul spoke especially of the believer's condition, Mark shows how a similar relationship existed between the Spirit and the Messiah himself. It stamped divine approval upon him at the beginning of his ministry, just as it attested the genuineness of one's claim to membership in the messianic community. ${ }^{13}$

In respect to faith in Jesus' messianic power, Paul had demanded only that the members of the apostolic church should acknowledge Jesus as Lord and believe that God raised him from the dead. ${ }^{14}$ Mark is inclined to carry even these primal items of early theology back to the period of Jesus' activity. When the disciples are fearful in the storm they are rebuked for lack of faith. ${ }^{15}$ Jesus' healing ministrations are often conditioned by the measure of the applicants' faith, ${ }^{16}$ and only a miraculous hardening of the heart can excuse the disciples for their dulness of belief when Jesus' power is so remarkably displayed as in the miracles of feeding, ${ }^{17}$ where the giving of thanks and the breaking of bread anticipated a privilege enjoyed by the apostolic church in its observance of the Lord's Supper. ${ }^{18}$ Even the fundamental tenet of apostolic theology, belief in Jesus' resurrection, is open to his followers prior to his death, but their dulness of understanding prevents them from attaining this height of faith. ${ }^{19}$ And the return of Jesus as judge in messianic glory, accepted by Paul as a corollary of the resurrection faith, is shown in Mark to be a matter

II E.g., I Cor. I2:4-II; Acts 2:38.

12 Gal. 3:2; cf. Acts 2:38; 10:47.

13 The gift of the Spirit in connection with baptism seems to have been emphasized by the Christians in contrast with the lack of any such phenomenon in the case of those who knew only the baptism of John the Baptist, or were perpetuating his movement in opposition to that of Jesus (Acts $19: 1-6$ ).

14 Rom. Io: 8 f.

15 Mark 4:40.

${ }^{16}$ Mark 2:5; 5:34, 36; 6:6; 7:29; 9:19, 23; 10:52.

17 Mark 6:52; 8:1 7-21.

${ }^{18}$ Mark 6:4I; 8:6.

19 Mark 9: 10, 32. 
of definite instruction on Jesus' part to help his disciples to believe. ${ }^{20}$ Here the element of immediateness may not be so vivid as in the earlier thought of Paul-a natural consequence of Mark's later date, but the element of certainty remains in full force. Thus "faith" in Jesus was required during his lifetime.

Paul and Mark represent a type of interpretation designed to reach those outside the circle in which Jesus had moved. In Paul's case this is self-evident, and Mark's gospel is clearly intended for gentile readers. All nations are brought within the legitimate range of the gospel, ${ }^{21}$ and Semitic expressions are carefully explained. ${ }^{22}$ In the controversy about clean and unclean meats Jesus is placed on Paul's side, though it is admitted that the disciples themselves were dull in comprehending this teaching, ${ }^{23}$ just as the Palestinian Christians of Paul's day failed to understand it. The writer's gentile interest also seems to have determined the form of the narrative. In the experience of the gentile convert baptism marked the beginning of vital interest in the new religion, as it marks for the second gospel the first significant incident in Jesus' career. On the other hand, in Jewish circles, where believers were not so conscious of any break with their past life but felt that they were carrying their old religion on to its proper fulfilment, earlier events in Jesus' career were given some prominence. Mark also has little to say of Jesus' teaching as a rule of life-his readers had no hereditary interest in the law of Moses so Jesus is not presented to them as a lawgiver. Of course his authority is superior to that of Moses $^{24}$ as all gentiles must believe, having been taught freedom from the bondage of the law.

Another form of tradition, suited to the needs of those believers who interpreted Jesus to his Jewish kinsmen, probably took shape at an early date. No pure example of this has been preserved, but its general character is fairly clear from certain features in the two great composite gospels, Matthew_and Luke. Each of these evangelists aimed at comprehensiveness in his composition, hence these writings have become the repository of both gentile and Palestinian

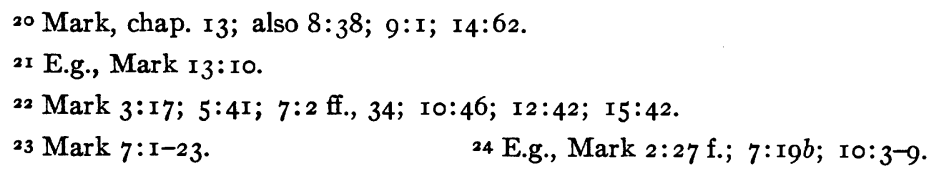


types of tradition, from earlier as well as from later times. The Palestinian elements in the tradition make it clear that also in this branch of the church stress fell upon Jesus' official significance. His messiahship was proved by (I) his teaching and by (2) his fulfilment of Old Testament prophecy-appropriate arguments for a Jewish setting. He also worked miracles but he is less distinctive in this rôle. His ability in this respect is not essentially different from that of other righteous men in Israel. ${ }^{25}$ As a new lawgiver, a second Moses, ${ }^{26}$ he was especially significant. The Jewish Christians could not feel that the new faith, when logically interpreted, implied the abrogation of the law; and they regarded as least in the kingdom of heaven all who, like Paul, taught men to discard certain Mosaic injunctions. ${ }^{27}$ Jesus was the messianic lawgiver who, by way of fulfilling rather than abrogating the law, placed his word above that which they of old had spoken. ${ }^{28} \mathrm{He}$ was also the one toward whom all messianic predictions had been directed. ${ }^{29} \mathrm{He}$ met the expectations of both the older prophets and the later apocalyptic seers. Belief in his speedy return to claim his own and pronounce judgment on his opponents was shared alike by gentile and Jewish Christians, but in the case of the latter, with their narrower range of vision, the return may have seemed nearer at hand, ${ }^{30}$ the gentiles were not included in the future outlook, ${ }^{3 x}$ and the condemnation of the Jews who disbelieved was made more emphatic. ${ }^{32}$

The writer of the Fourth Gospel is also primarily interested to

25 Matt. I2:27=Luke II:I9; cf. Luke I0:18-20.

${ }_{26}$ Matt. $5: 17$ ff., cf. Acts $3: 22 ; 7: 37$.

27 Matt. 5:18 f.

${ }^{28}$ Matt. 5:2I-48.

29 Matt. I:22; 2:15, etc.; Luke 4:21.

30 Matt. 10:23.

31 Matt. 10:5 f., 23; 19:28. Such passages in Matthew are often put side by side with universal ideas, e.g., I0: $18 b ; 20: 1-16$.

32 E.g., Matt. $12: 38-45$. It is very true that judgment on unbelieving Jews became a favorite doctrine in many gentile circles. The first Gospel is written from this point of view; while Luke is primarily interested in the reception of the gentiles, and only secondarily in the casting-out of Jews. With Paul approval at the day of judgment is not a matter of favoritism for either Jew or gentile, but a question of spiritual attainment through faith (Gal. 5:19-24: cf. Mark 7:20-23); nor can Paul reconcile himself to the thought that his Jewish kinsmen will ultimately be cast out (Rom. II $: 23$ f.). 
establish faith in Jesus as the Messiah, the Son of God. ${ }^{33}$ Jesus is both the mighty wonder-worker and the divine teacher, determining the destiny of men according to their acceptance or rejection of his claims. Nobody is left without excuse-openly and everywhere Jesus works the works of God and teaches the truth which he has received directly from God. As his career progresses men fall into two classes: those who gradually and yet falteringly attain to faith, and those who persistently disbelieve. The former are the disciples, some of the common people, and a few Greeks; among the latter is the great mass of the Jewish people, especially the leaders in religion. Chaps. I-I2 give an account of this sifting process and make the resurrection of Lazarus the last great "sign." The remainder of the gospel deals chiefly with the training of the disciples and their introduction into the fulness of resurrection faith.

Belief in a risen Jesus is the uppermost interest of all these early Christian writings, and the story of his life is told in defense of this faith. For each evangelist his resurrection is the climax of the gospel. There was a perpetual interest among Christians to show that he displayed in his lifetime qualities befitting a person who was to become the heaven-exalted Lord they now believed him to be. Naturally, it was only by degrees that a satisfactory type of interpretation along this line was reached. Paul-and perhaps the same thing is true of the earliest believers in general ${ }^{34}$ - usually represented that God raised Jesus. Mark speaks of the event in the active voice: Jesus will rise; yet Mark makes it clear that the disciples had not comprehended the meaning of Jesus' teaching on this subject. ${ }^{35}$ Even in the synoptic gospels there are intimations that Jesus had ability to raise others from the dead, as in the case of Jairus' daughter and the widow's son, but there is no publicity attached to such incidents so the disciples are not severely condemned for lack of faith. But if Jesus had this power why had he not demonstrated it more openly in order to prepare men to believe in his own resurrection? This question was easily raised, and various answers were attempted. In some quarters the question was declared to be improper; it was an evil generation which sought a sign and no sign would be given..$^{36}$

33 John 20:31.
34 Cf. Acts $2: 32,36$.
35 Mark 8:30-32; 9:9 f.; 30-32.

${ }^{36}$ Mark 8: 12. 
Other interpreters understood Jesus to have said something about the sufficiency of the sign of Jonah, but some thought he had reference to the character of his teaching-the sign of a great call to repentance, ${ }^{37}$ while others took it as a veiled reference to his own burial and resurrection. ${ }^{38}$ Another phase of tradition distinctly declared that a "resurrection" sign would be of no avail: if the Jews would not believe Moses and the prophets-and Jesus had been preached to his own countrymen as the second lawgiver and the fulfilment of Old Testament prophecy-they would not believe even a messenger from the dead. ${ }^{39}$ In the Fourth Gospel even this excuse is no longer possible: Lazarus does return and they only disbelieve the more. $4^{\circ}$

In all this early literature stress falls on the religion of believers and not on the personal religion of Jesus. He was presented as a supreme object of faith. But that this indicates the full significance of his relation to the first Christians, or that it touches the most fundamental item in the relationship, is less certain. Behind all the interpretative apologetic of the disciples lay their personal experience with Jesus. The impress his life left upon them was such that they found no inconsistency in ascribing to him the most exalted ideas possible to the theological thinking of the age. Nor was it his official dignity that chiefly impressed them during his earthly life. Even according to the tradition now extant, they did not recognize his messiahship until near the close of his ministry, they failed utterly to comprehend his reference to his death and resurrection, they forsook him at his trial, and disbanded after his death. During his lifetime they may have hoped he would declare himself to be Israel's deliverer, and some bolder individuals such as Peter may have openly expressed the conviction that he would, but such thoughts seem to have had no very definite content, nor were they altogether extraordinary. Other leaders had inspired similar hopes in their followers. Moreover, for Jesus' disciples the coming of the kingdom was a thing of the future, conditioned upon some further demonstration of God's favor for Jesus. Once convinced that the divine favor was removed-and Jesus' death was at first taken to mean this-their messianic faith vanished.

37 Luke I I :29-32.
$3^{8}$ Matt. I $2: 39 \mathrm{f}$.
39 Luke I6:31.

40 John I I : 47-53. 
The message they heard from the cross was not one of victory but one of defeat: "My God, my God, why hast thou forsaken me?"

The memory of personal association with Jesus could not be so easily dismissed. As their faith in his official significance during his lifetime was only secondary to their response to his message about God and their consciousness that he touched many a sensitive chord in their own religious lives, so after his death they probably suffered more keenly the loss of daily fellowship with him than the abandonment of their faltering messianic faith. The impress his personality left upon them contained an element of vitality, interpreted by them in terms of resurrection faith, which was more enduring than all their former messianic expectations, and in turn became the basis of a new messianic hope. Thus the secret of Jesus' influence on the disciples must be found in the content of his own religious life during the period of his association with them. Ultimately it was his power as a religious individual that made possible the early faith: the personal religion of Jesus is the foundation of the disciples' religion about Jesus.

Though their new life was closely bound up with certain ecstatic experiences, in the common daily walk of the early believers the earthly Jesus came to life again in their memory. They ate together in loving recollection of their former fellowship with him, they recounted his deeds of kindness, and they felt a new power in the words he had spoken. While doubtless they interpreted all these things in the light of their new faith in the heavenly Messiah, they also preserved much that reflected the personal side of Jesus' life. Hence when moderns use the gospel records to recover information about Jesus, a distinction must be made between those phases of tradition which are more formal and those which appear to be, in the main, uninfluenced by special doctrinal interests. We shall expect to find the actual religion of Jesus represented most truly by the words and deeds that are reported in connection with the scenes of his ordinary daily living. The results of modern literary criticism enable one to fix upon certain early source elements in gospel tradition, but this does not finally determine the traditions' freedom from subjective elements. Even the earliest document was an apostolic product and so likely to embody some of the special tendencies of early theologizing. 
Ultimately one must resort to the historical test, that is, the elimination of everything which clearly was, or was likely to have been, created in the interests of early interpretation.

It is necessary, too, to remember that Jesus' personal religion is concrete, in contrast with formal and abstract theories about his person. He stood in definite relations. He was connected with a past which played its part in the process of his development, he was surrounded by definite historical circumstances, and he had his own personal inclinations, his own emotional characteristics, his own intellectual life and his own spiritual experiences.

A variety of elements necessarily enters into the religious life of any individual. For convenience, in attempting to discover the actual content of Jesus' religion one may seek: (I) those items that belong primarily to his experience, (2) his interpretation of experience, and (3) his way of relating religion to life. The first will deal with the source elements in his religion, the second with the doctrinal content of his faith, and the third with the ethical and social aspects of his thought.

The sources of Jesus' religion must have been manifold. $\mathrm{He}$ inherited richly from the past. For centuries the Jews had inculcated in their children reverence for God and loyalty to his cause, and from this atmosphere Jesus had doubtless absorbed many things that were determinative for his career. His contact with the professional religionists of his time may not have been intimate, but he probably suffered no great disadvantage on this account. The cultivation of the pious life through the consciousness of God's nearness to his people was quite as possible in remote Nazareth as in the Holy City; indeed those who were free from the constant demands of external ceremony were, on that very account, more likely to preserve a deeper spiritual vitality. Heart purity, pious conduct, sincere motives, and humility before God were less stimulated by attendance upon the temple services than by the study of the great religious teachers of the past; for instance, the words of Micah: "Wherewith. shall I come before Jehovah, and bow myself before the high God? Shall I come before him with burnt offerings, with calves of a year old? Will Jehovah be pleased with thousands of rams, with ten thousands of rivers of oil? Shall I give my first-born for my trans- 
gression, the fruit of my body for the sin of my soul? He hath showed thee, O man, what is good; and what doth Jehovah require of thee, but to do justly, and to love kindness, and to walk humbly with thy God?"

The Jewish Scriptures in general must have exerted a strong influence upon Jesus. In the course of his teaching he shows much familiarity with this literature. He frequently quotes it, sometimes in criticism but oftener with approval, and he gives ample evidence of having absorbed its spirit. As would be expected from his early training, his sympathy with the prophets was especially close. His career seemed in many respects a repetition of theirs, his preaching resembled theirs in that he stood for the moral issues in contrast with ceremonialism, and he anticipated for himself a fate like theirs in the sacred city which had stoned the prophets.4I He also drew from the lawgivers and the sages. The law which required love for God with all one's heart and the love of neighbor as oneself was accepted by Jesus as fundamental. Likewise the sage's emphasis upon practical precepts and individual right living found a large place in his teaching, but behind all these lay the prophet's consciousness of an immediate relationship between man and God.

A more specific factor in influencing Jesus, and one more directly connected with his appearance as a public teacher, was his contact with John the Baptist. Just what his experience was in this connection began to trouble interpreters at an early date. That he came to John's baptism of repentance might seem incompatible with his consciousness of purity, and indeed his baptism furnished a distinct doctrinal difficulty when his sinlessness became an item of dogma. Various suggestions were made to obviate the difficulty. The uncanonical Gospel according to the Hebrews explains the event as follows: "Behold the Lord's mother and brothers said to him, John the Baptist is baptizing for remission of sins; let us go and be baptized by him. But he said to them, What sin have I done that I should go and be baptized by him; unless perhaps what I have now said is ignorance?" This has sometimes been treated as a genuine saying, but it probably is a later development of tradition. It attaches a

4I Matt. 23:37. Jesus' anticipation of stoning at the hands of the mob points to the genuineness of the passage. 
sacramental significance to baptism, making the ordinance efficacious for a sin of ignorance; and the whole story seems to have arisen by projecting into Jesus' pre-public career the same misunderstanding of his true character which, according to Mark, his relatives shared during his ministry. The Gospel of Matthew offers another explanation. John's objection is overruled by the words: "Suffer it now, for thus it becometh us to fulfil all righteousness." When baptism became a recognized church ordinance Jesus' action seemed best explained as an example for his followers. For the Fourth Evangelist the baptism of Jesus and the descent of the Spirit were chiefly for the benefit of John. Thus he was enabled to recognize the Messiah and to point him out to his own followers.

No one of these explanations is sufficiently well attested to justify its use in determining the experience of Jesus. At the time there was no occasion for any explanatory comments; the procedure was a perfectly natural one on Jesus' part. John indeed preached repentance and coming judgment, but he also put stress upon the positive qualities of a holy life- "bring forth fruit worthy of repentance." ${ }_{42}$ Personal purity of life was a prerequisite for membership in John's community, just the type of life after which the pious people of the land were daily striving. Others must repent and forsake their sins, but it would be unsafe to suppose that only persons of this class came to be baptized-as absurd as to conclude that everyone in modern times who joins a movement for social betterment must previously have been a social outcast. All that may be inferred from Jesus' action in coming to John's baptism is that it marked a decisive step in his active life. It was the response of his own pious life to the religious ideals for which John stood.

As a result of this action Jesus' religious experience would naturally be quickened and deepened. According to early tradition he received at this time an official declaration of his messiahship; but the baptismal incident is told so briefly, and in a form that lies so close to

42 Josephus says of John's baptism: "It signified the purification of the body, supposing that the soul was thoroughly purified beforehand by righteousness ( $A$ nt. xviii, 5. 2.) According to Matt. 2I:32 Jesus said: "John came unto you in the way of righteousness." This is often called a characteristic addition of the First Evangelist; but it agrees with Mark's account of John, the righteous and holy man whom Herod feared. 
the peculiar interests of the early theologians, that it does not clearly reveal the actual content of Jesus' experience. This picturesque description - the rending of heaven, the descending dove, and the audible utterance of God-shows the primitive Christians' fondness for vivid imagery, while the prominence given to the ecstatic element in their own lives easily led them to interpret Jesus' experience in terms of ecstasy. It is a question whether the primal item in his experience at this time was not his sense of new consecration to God as a spiritual father rather than a recognition of God's choice of him as a messianic son. The account of his temptation which tradition has placed in close connection with his baptism may have been framed to furnish scriptural authentication for Jesus' failure to display at once messianic prerogatives, yet it testifies to the fact that he did not, as the early Christians well knew, at the beginning of his ministry present himself as Messiah-at least not as the type of Messiah currently expected. And if he entertained the idea at all, he possessed some deeper experience which impelled him to reinterpret this as well as other ideas of the time. The messianic thought did not master him; he was its conqueror not its victim, and he attained this position by placing more stress upon his choice of God than upon God's choice of him.43 His first interest was not to claim the favors due one who deemed

43 Evidence that Jesus' consciousness of sonship was primarily a spiritual experience, based upon his own choice of God as Father, may still be seen in Luke's account of the baptism. In Luke 3:2I both the baptism of the people and that of Jesus are mentioned as simple events (expressed by aorists) falling in the same general period of past time, while Jesus' special experience comes to him during a season of prayer following his baptism (see Biblical World, XXXI, 4, 300-302). These have usually been considered as secondary traits in Luke, but the opinion is open to doubt. The non-Markan source, conveniently termed $Q$, probably mentioned the baptism (so Wellhausen, Einl., p. 74 and Harnack, Sprüche und Reden Jesu, pp. I36, 2 I 8 f.), and the variant reading in Luke $3: 22$, "Thou art my son, today have I begotten thee," seems originally to have been taken from Q by the Third Evangelist himself. $Q$ also may have supplied the note about Jesus' prayer. This source remembered that he continued to address the "Father" in prayer (Matt. II:25; Luke I0:21), and taught his followers to do the same (Matt. 6:9 ff.; $5: 45$; Luke $11: 2-4 ; 6: 28$ ). According to this branch of tradition which being Palestinian in origin attached less initial significance to baptism, at the very beginning of Jesus' public career he showed the same devotional attitude that characterized his ministry to the end. After his baptism he sought with renewed determination to know the Father's will, and in answer to his cry "(my) Father," there came the response "(my) Son." Thus his renewed choice of God as Father was fundamental to his new sense of sonship, and the relation was primarily ethical and spiritual rather than external and official. 
himself to be God's son-even a messianic son-but to maintain that course of life which one should pursue who had made absolute choice of God. It was Jesus' never ceasing care to learn and to do the divine will, and his unfaltering and permanent choice of the Father is the basis of his unique consciousness of sonship. Not only did he thus attain and maintain his own filial relations with the divine, but he advised others to follow a similar course in order to become sons of God.

The problem of Jesus' messianic self-consciousness is too complicated for extended treatment here, as it would unduly prolong discussion and might divert attention from the immediate subject, his personal religious life. Whatever his thought may have been about his official significance, it does not seem to exert any large influence upon his daily experience; and this fact appears even in those narratives which give prominence to his official character on special occasions. Thus when he calls disciples he does not offer them the glories of a messianic kingdom but an opportunity to become "fishers of men"; and later when they question about relative positions in the kingdom he sets before them the ideal of humble service. In his controversy with opponents it is not by virtue of his own dignity but through his deeper spiritual insight that he justifies his contentions; as when he refuses to be bound by current notions about the sabbath, or condemns the "corban," on humanitarian grounds. Again, in the conduct of personal life it is his vital spiritual fellowship with the Father, rather than the thought of official authentication, from which he draws his real help. When weary he retires alone for prayer, and at the last great crisis while in the garden of Gethsemane he ultimately finds assurance not in a renewed conviction of his messiahship but in the consciousness of having submitted himself unreservedly to the Father's will. In all this it is his sense of God's nearness and his determination to choose divine guidance which stands out most distinctly. The fundamental item in all Jesus' religious experience appears to be his abiding consciousness of fellowship with the Father.

One of the first problems of interpretation to engage Jesus' attention must have been that of determining the character of his mission. This question confronted him as soon as he decided to take up public 
work. All Israel was looking for salvation and any teacher seeking a public hearing must be prepared to pronounce upon that subject. God was the ultimate ground of all hope, but various ways were being advocated as the best means of inducing him to act in men's behalf. Some held that the strict observance of ordinances was the only way to win the divine favor, but this was emphatically rejected by Jesus and among its advocates he found his severest opponents. The Zealots proposed another method. They would resort to the sword, trusting that God would interfere in their behalf; but Jesus refused to sanction political revolt and admitted the propriety of paying tribute to Caesar. Still others placed chief stress upon a righteous life as a means of securing the divine favor. This view was supported by much that the older prophets had taught, as well as by the writings of the earlier and later sages. Two centuries before Jesus the son of Joseph began his work, Jesus the son of Sirach had said:

Ye that fear the Lord, put your trust in him, And your reward shall not fail.

The eyes of the Lord are upon them that love him.

A mighty protection, and a strong stay.

The Most High hath no pleasure in the offerings of the ungodly, Neither is he pacified for sins by the multitude of sacrifices.

To depart from wickedness is a thing pleasing to the Lord;

And to depart from unrighteousness is a propitiation.

Have mercy upon us, O Lord the God of all, and behold;

And send forth thy fear upon all the nations;

Lift up thy hand against the strange nations;

And let them see thy mighty power. 44

About a century later a similar assurance that God will ultimately vindicate the righteous appears in the Wisdom of Solomon:

The souls of the righteous are in the hand of God,

And no torment shall touch them.

For even if in the sight of men they be punished,

Their hope is full of immortality. 45

44 Eccles. 2:8; 34:16, I9; 35:3; 36:I-3.

45 Wisdom Sol. 3: I, 4 
Again, the wicked, speaking of the righteous man, says,

He professeth to have knowledge of God, And nameth himself servant of the Lord.

The latter end of the righteous he calleth happy;

And he vaunteth that God is his Father.

Let us see if his words be true,

And let us try what shall befall in the ending of his life.

For if the righteous man is God's son, he will uphold him,

And he will deliver him out of the hand of his adversaries. ${ }^{46}$

To some extent Jesus shared these views. He demanded a life of righteousness for the individual, he did not identify trial and suffering with defeat, he taught that God freely forgave the sins of the repentant, that he sustained men in affliction, that he cared for the lowly, that he gave assurance of immortality, that he revealed himself to the righteous, that the righteous man had God for a father and was God's son. But in one important respect Jesus deviates from all these teachings: he does not make the hope of favoritism from the divine the principal aim of righteous living. The highest privileges of sonship are not to be identified with temporal blessings, but lie in the opportunity to live the Godlike life in which love, mercy, and self-giving service are dominant to the end.

When Jesus determined that the preaching of this truth was to be his chief mission, he went quite beyond the religious outlook of his contemporaries. Here he shows his method of interpreting the current messianic hope. As that doctrine was popularly held, it rested mainly upon the idea of favoritism. This was read into the early history, as seen in Moses' words to Pharaoh: "Thus saith Jehovah, Israel is my son, my first-born; and I have said unto thee, Let my son go: behold I will slay thy son, thy first-born." Here is God's favoritism for his chosen people expressing itself in vengeance on their enemies. Even in Jesus' day this was the essential content of Jewish messianic thought, but it was so at variance with Jesus' fundamental thought that he can hardly have avoided criticizing it along with other ideas that were lacking in ethical efficiency. Moreover, the prophets had criticized it and John had partially condemned it when he warned the Jews not to trust in Abrahamic

${ }^{46}$ Wisdom Sol. $2: 13,16 b-18$. 
descent for future safety. Jesus went still farther in his criticism. Like John, he did appeal to men to live a righteous life, not however with the ultimate motive of winning God's favor in the day of judgment but in order to attain genuine sonship in the present. This was the way of true salvation, the present realization of the messianic hope, and as the minister of this truth Jesus may indeed have deemed himself the Messiah. On one occasion John is reported to have sent messengers asking Jesus if he is this final minister of salvation. In substance he replies affirmatively, but the proof of his claim was not to be looked for in the establishment of a miraculous judgment of sifting and purging as John had preached. Rather his Godlike life of service for mankind was his testimonial. Of course he does not deny the reality of divine favor, and in fact he makes it displace the narrower conception of the divine favoritism: God's blessings abound toward all men, the wealth of his love is unlimited, he desires all to share in his goodness by making absolute choice of him.

Jesus' doctrine of salvation is determined by this thought of God's activity among men. He is regnant here and now. The nature of his rule is fatherly, he discards all narrow favoritism, he gives himself unreservedly to the interests of humanity, and the ideal for humanity is the realization, on its part, of the Godlike life. Jesus prescribes no other doctrinal programme for the attainment of salvation: become sons of God in childlike, trustful fellowship, and under the inspiration of this fellowship live the life of unselfish service. It is the urgent desire of God that all men should enter into the full realization of this new life, he is ever encouraging them to do so, and Jesus' work is all directed toward this end. But it is for man to say whether or not he will enter into this new relation. There is no barrier between him and God save that which his own will has erected.

This is the soteriology of Jesus, and its simplicity has almost been its undoing. It lacks the Pauline dialectic, it is free from the theological intricacies of later times. It attaches no vital importance to any form of organization, and it presupposes no theory of infallible mediators whether in the form of books or persons. It centers attention on two things: on the one hand is God, immediate, loving, inviting; on the other is man with a free spirit holding his destiny 
in his own hand. Will he commit his way unto God, and walking in harmony with the divine spirit realize the highest ends of life? Or will he refuse, living for self and the world, and so suffer the unspeakable calamity of shutting God out of his life?

But how shall men get rid of the debt which past sins have laid upon them? Must they not by some means placate an angry God whose mandates have been disobeyed and whose dignity has been insulted by rebellious humanity? Jesus knew no such angry deity. His father would gladly receive every penitent who came; forgiveness for the past was procured by the very desire to forsake it and to live the new life. The real problem was not how to escape the anger of God, but how to break the power of sin which hindered the attainment of the higher life; and Jesus had a remedy for this evil. His contemporaries talked of judgment from which only those would escape who had succeeded in getting rid of sin before God came, while Jesus preached that God is now present delivering men from their bondage. Personal alliance with the Father is the secret of escape from the present power of evil. Getting rid of sin, instead of being a prerequisite to the divine coming is an integral factor in its realization. Man's receptivity for the divine rather than his perfect attainment of holiness conditions the coming of God, and without his presence in life the hope of any worthy attainment is meager. Here is one of the most distinctive features of Jesus' religious thinking: God's presence means salvation, and Jesus, revealing this truth in his own career, is the great minister of salvation.

In its more external features, the theological thinking of Jesus corresponded in general to the intellectual ideas of that age. The modern outlook upon the world and its history was then unknown, consequently it is vain to look for this in his teaching. He did subject various ideas of the time to criticism and correction, yet not on scientific but on religious grounds. For example, men then talked of angels and demons in a realistic way and so did Jesus, but in contrast with Jewish transcendentalism, and the attendant development of angelology, he brought God back from the remote regions and made him walk again with men in true spiritual communion. This was no denial of angels' existence, but they could no longer be thought to serve any important religious function. Also belief in 
evil spirits was not denied, but their power was practically abolished by faith in the nearness and supremacy of God. Similarly other phases of Jesus' teaching employed current thought and terminology, but their essential content was determined by the new vitality of his personal religion. His whole theological method was controlled by his own deep religious experience.

Jesus' religion had also important ethical and social aspects. The conditions of society and the point of view of that age differed so much from those of modern times that the real import of his teaching has not always been grasped. We cannot assume that he had definitely in mind all the problems of modern society, nor is it fair to give his words and deeds the interpretation which modern conditions might place upon them. Perhaps he would have taught and acted otherwise had he been placed in these modern surroundings. So far as his specific words are concerned, they should always be interpreted in the first- and not in a twentieth-century setting; while for the purposes of modern application one must seek the general principles underlying his specific teaching. These are always fairly evident.

Jesus lays down two controlling principles for the guidance of conduct: God is to be loved with full devotion of heart, soul, and mind, and one's neighbor is to be loved as oneself. Each principle carries with it many practical implications. The first means nothing less than a determination to make God's conduct an absolute standard for life, the rule of the divine is the ideal of human action, sons are to live as the Father lives and to be perfect as he is perfect. Therefore genuine sincerity of motive must characterize all life; so men are exhorted to maintain secrecy in almsgiving in order to guard against pride and hypocrisy, to preserve the genuineness of their devotions by praying to be heard of God and not of men, and, if they choose to fast, to make it a season of secret personal discipline. In the life of the true son no place is to be allowed that type of selfishness which seeks such credit from men as a disfigured countenance, a wordy prayer, or a public demonstration of generosity might prompt. Jesus seeks to inspire all the motives of life with these fundamentally unselfish qualities.

The character of all action is determined by the ideal relationship 
between the Father and his sons. They will put his cause first, seeking his kingdom and his righteousness at the cost of all lower ideals; they will be optimistic yet trustfully submissive to the divine will, and they will live the same sort of self-giving life as does he. If he loves all men so must they; if he abhors favoritism they must do likewise; if his interest is to seek and save the lost this must also be theirs; if self-seeking is eliminated from his attitude they must strive to abandon all selfish thoughts; if it is characteristic of him to forgive and forbear they must practice forgiveness and forbearance, in short their entire conduct toward their fellows will be modeled after the perfect standard set by the Father. These were the controlling principles in Jesus' own life. He cast in his lot with the poor and lowly, he despised not the needs of publicans and sinners, he freely gave himself for the sake of others, and when he was smitten he smote not in return but forbore and forgave because he believed this also to be the Father's will.

Such, in outline, is the personal religion of Jesus. His serene faith withstood all the storms that beat against it because it was founded upon the consciousness of vital communion with God. His whole theological thinking was dominated by this personal experience of a divine father whose presence in the world meant a full salvation and whose contact with men inspired them to live the life of ideal social service.

The secret of Jesus' supremacy is his own loyalty to this ideal of a life of unhindered fellowship with God. The maintenance of harmonious relations with the divine, and the emulation of the Godlike life in one's own life, is still a great religious ideal. Moderns may wish to phrase it in more secular language and call it the establishment of right relations with the universe, or it may be stated in the warmer, richer phraseology of Jesus and called the demand for the realization of spiritual sonship to God. But struggle as we may with terms the ideal remains, and not the least important feature in Jesus' significance for modern men is the fact that his religious life reveals the secret of transforming the ideal into the real. 